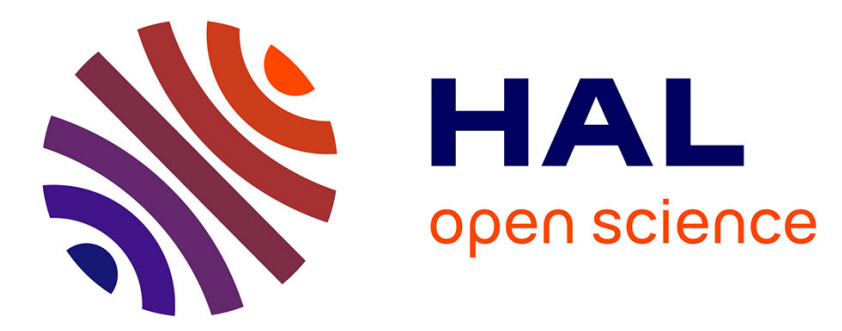

\title{
Unlikely Democrats: Economic Elite Uncertainty under Dictatorship and Support for Democratization
}

\author{
Michael Albertus, Victor Gay
}

\section{To cite this version:}

Michael Albertus, Victor Gay. Unlikely Democrats: Economic Elite Uncertainty under Dictatorship and Support for Democratization. American Journal of Political Science, 2017, 61 (3), pp.624-641. 10.1111/ajps.12277 . hal-02523084

\section{HAL Id: hal-02523084 \\ https://hal.science/hal-02523084}

Submitted on 2 Apr 2020

HAL is a multi-disciplinary open access archive for the deposit and dissemination of scientific research documents, whether they are published or not. The documents may come from teaching and research institutions in France or abroad, or from public or private research centers.
L'archive ouverte pluridisciplinaire HAL, est destinée au dépôt et à la diffusion de documents scientifiques de niveau recherche, publiés ou non, émanant des établissements d'enseignement et de recherche français ou étrangers, des laboratoires publics ou privés. 
Article title

\title{
Unlikely Democrats: Economic Elite Uncertainty Under Dictatorship and Support for Democratization
}

\author{
Short title for the running header \\ Unlikely Democrats
}

Keywords: dictatorship, elites, democratization, formal models.

Michael Albertus is an Assistant Professor, Department of Political Science, University of Chicago, 5828 S. University Avenue, Pick Hall 426, Chicago, IL 60637 (albertus@uchicago.edu).

Victor Gay is a Graduate Student, Department of Economics, University of Chicago, 1126 East 59th Street, Chicago, IL 60637 (victorgay@uchicago.edu).

\footnotetext{
${ }^{0}$ We thank Ben Lessing, Richard Van Weelden, participants of the University of Chicago Harris School Political Economy Workshop, and three anonymous reviewers for very helpful comments. Albertus also acknowledges support from the Hoover Institution for research leave.
} 


\title{
Unlikely Democrats: Economic Elite Uncertainty Under Dictatorship and Support for Democratization
}

\begin{abstract}
Influential recent scholarship assumes that authoritarian rulers act as perfect agents of economic elites, foreclosing the possibility that economic elites may at times prefer democracy absent a popular threat from below. Motivated by a puzzling set of democratic transitions, we relax this assumption and examine how elite uncertainty about dictatorship - a novel and generalizable causal mechanism impacting democratization - can induce elite support for democracy. We construct a noisy signaling model in which a potential autocrat attempts to convince economic elites that he will be a faithful partner should elites install him in power. The model generates clear predictions about how two major types of elite uncertainty - uncertainty in a potential autocratic successor's policies produced by variance in the pool of would-be dictator types, and uncertainty in the truthfulness of policy promises made by potential autocratic successors - impact the likelihood of elite-driven democratization. We demonstrate the model's plausibility in a series of cases of democratic transition.
\end{abstract}

Replication Materials: The data, code, and any additional materials required to replicate all analyses in this article are available on the American Journal of Political Science Dataverse within the Harvard Dataverse Network, at: http://dx.doi.org/10.7910/DVN/3DMNPE.

Word Count: 8,986 


\section{Introduction}

Scholars have long noted the critical role that economic elites play in shaping regime outcomes. Most authors argue that they are typically anti-democratic: whether by capturing the state to deliver favorable policy (Marx \& Engels 1848), meting out labor restrictions or repression on workers to ensure a supply of cheap labor (Moore 1966), or using their economic influence to buy off voters or commit fraud (Ziblatt 2009), economic elites are better off when they can play by their own rules rather than those set by the median voter under democracy.

Autocratic rulers, for their part, ignore economic elites at their peril. Sympathetic elites can deliver societal support or quiescence to dictatorship and aid in coercion and repression, often through formal positions in a regime party or a legislature (e.g., Gandhi \& Przeworski 2007, Magaloni 2008). They can also hold informal power through their control of the levers of the economy. Examples include ownership of the banking system, control over agricultural production, and ownership of the press. In short, economic elites are often critical to autocratic regime survival, leading dictators to draw them into their ruling coalitions or otherwise ally with them.

The strength of these arguments along with substantial historical evidence has led influential recent contributions to assume that authoritarian rulers act as perfect agents of economic elites (Acemoglu \& Robinson 2006, Boix 2003). These contributions foreclose the possibility that economic elites may at times prefer, and even lead the push for, democracy - unless they are forced to democratize due to a threat from below (Acemoglu \& Robinson 2006).

This paper relaxes the assumption that economic elites will necessarily support dictatorship first and foremost, and explores the implications this holds for democratization. We draw on insights from three related literatures. The first is the literature on property rights and institutional constraints, which emphasizes that autocracies are associated with fewer institutional constraints to rule than democracies, enabling them to violate property rights more easily (e.g., Albertus 2015, Ansell \& Samuels 2014, North 1990). The other two lit- 
eratures are those on expropriation and on state autonomy, which indicate that autocratic rulers often have incentives to attack elites and exclude them from their ruling coalitions. They do so to credibly signal their loyalty to the support coalition that initially brought them into power, to enhance their autonomy in office, and to eliminate powerful threats to their rule (e.g., Albertus \& Menaldo 2012, Trimberger 1978).

These insights have important implications for economic elites' calculations regarding whether to support continued autocratic rule or a shift to democracy. Economic elites face at least two major sources of uncertainty when determining whether to back an existing dictatorship or to push for democracy. We refer to these below as "elite uncertainty."

The first is uncertainty in the pool of potential subsequent autocrats. Data from Archigos (Goemans, Gleditsch \& Chiozza 2009) indicate that since 1875, over 90\% of dictators have been replaced by new dictators, and median dictator tenure in office during this period is 2.01 years. Only a quarter of dictators have survived in office five years or longer. Long-term survival is the exception rather than the rule. Given the leader cycling that is often common under dictatorship, elites have ample reason to be concerned about who the next ruler might be. What policies will the next dictator implement once the current dictator is toppled or hands over power? If the pool of potential autocrats is sufficiently homogeneous and predictable, perhaps due to institutionalized selection mechanisms, economic elites can form reasonable expectations about future policies under a new dictator. However, a new draw from a widely varying pool (e.g., an expanding military where the social basis of recruitment is becoming more varied) may yield a dictator who has no affinity to elites and who will seek to destroy them through expropriation in order to signal exclusive loyalty to the group that brought the dictator to power. This first source of uncertainty can push economic elites to tilt toward favoring democracy even absent a credible threat from below.

Because potential autocrats know that this first type of uncertainty shifts economic elites' relative benefits from dictatorship downward, they have incentives to attempt to signal to economic elites that they will be faithful partners. The fidelity of these signals is a second 
source of elite uncertainty. A potential autocrat that is a member of or a close ally of economic elites will make promises to faithfully implement policies preferred by elites. However, so will a potential autocrat who would in fact find it expedient to gain elite backers to become the next dictator, and then excise elites from the ruling coalition and instead appeal to the masses or a narrow military or personal coalition. Aware of this manipulation on the part of potential autocrats, economic elites exert caution in separating the wheat from the chaff. Yet the environment in which the communication between elites and potential autocrats takes place generates uncertainty. Political instability or a fractionalized and relatively autonomous military, for instance, complicates the ability of elites to extract any precise information from the potential autocrat's signals, thereby deteriorating their capacity to detect faithful partners.

Economic elites facing uncertainty about what dictatorship will bring in the future have incentives to abandon dictatorship altogether and instead support democratization when their expected payoff from dictatorship is sufficiently low. This is especially true if elites anticipate that they will not be ruined under democracy, or if they play a role in guiding the transition and shaping subsequent institutions. Such outcomes are not uncommon. Economic elites frequently win favorable transition bargains that incorporate elite demands such as constitutional prohibitions on expropriation (e.g., Wood 2000). In other circumstances, their substantial de facto power (Acemoglu \& Robinson 2008) or the presence of elite-biased institutions or strong conservative parties that can credibly and effectively represent their interests (Albertus \& Menaldo 2014, Mainwaring 1999) endows them with the ability to safeguard their privileges under democracy.

This paper argues that elite uncertainty under autocracy can and does play an important role in spurring democratization. In doing so, it puts forth a novel and generalizable causal mechanism that can help to explain a range of cases of democratization that are puzzling under existing theory. Drawing from Cunningham \& de Barreda (2015), we construct a noisy signaling model in which a potential autocrat attempts to persuade economic elites that he 
will be a faithful partner should the elites install him in power. This allows us to generate clear predictions about how elite uncertainty may affect the elite's incentives to democratize. In particular, we find that higher uncertainty in the pool of potential autocrats, as well as a noisier informational environment, induce economic elites to push for democratization more often. We then provide an illustrative overview of a number of cases in which the mechanism we propose has operated.

We do not argue that elite uncertainty plays a role in all cases of democratization. Transitions also occur from below, through foreign imposition, and despite resistance from economic elites. Nor are we the first to note that elites in general can play a crucial role in democratization (see, e.g., O’Donnell \& Schmitter 1986, Przeworski 1991). Yet our contribution is distinct in that we focus on the division between political elites and economic elites rather than splits among political elites, and that we focus on elite uncertainty amidst splits, and not splits per se, as generative of elite-led democratization. Furthermore, our mechanism of elite uncertainty spurring democratization is flexible, and can operate whether economic elites are incorporated in the existing authoritarian regime or not.

This paper builds on an important burgeoning literature of models of nondemocratic politics, and in particular on models that highlight the prevalence of commitment problems in autocracies (Boix \& Svolik 2013, Gehlbach \& Keefer 2011, Myerson 2008). We draw on key insights from these models, but make two distinct contributions. First, in exploring the consequences of information asymmetries between economic elites and "dictator candidates" for the first time, we generate insights into how commitment problems not only shape dynamics under authoritarian rule but also the decision by economic elites to forego dictatorship entirely when it is rife with uncertainty and instead support democratization. Second, our model is distinct from other models of nondemocratic politics - indeed, from other formal models in the broader literature - in that its main implications rely on comparative statics around equilibrium from the variance of the distributions of the key variables, rather than the variables themselves. At the core of our model, this feature sheds original light on the 
critical role of uncertainty in political regime dynamics, and could potentially be integrated fruitfully into other existing models.

\section{$2 \quad$ Framing the puzzle}

There are a host of literatures on the origins of democracy. Scholars point to factors such as modernization, natural resource dependence, inequality, economic openness, international diffusion, negative economic shocks, and previous experience with democracy as playing a critical role in regime transitions 1$]$ There are, nonetheless, a number of cases of democratization that are puzzling from the perspective of several or even all of these literatures.

Consider, for instance, many of the transitions and subsequent regime trajectories during democracy's second reverse wave or third wave. Schmitter (2010) calls many of them a "divine surprise." In transitions in Latin America and Southern Europe during this period, "many of the factors said to be vital (or at least helpful)...have been missing in many if not most of these cases" (Schmitter 2010, 19). Economic inequality was high, middle classes were underdeveloped, and societies were hardly rich or imbued with solid democratic experience or values. The transitions in Central and Eastern Europe and the former Soviet Union were even more surprising to contemporary observers. Indeed, a wave of scholarship sprung up trying to explain why authoritarian regimes in these countries collapsed so quickly and unexpectedly (e.g., Kuran 1991), to be replaced in succession by new, democratic regimes. More recently, "unexpected" democratic shifts have transpired in sub-Saharan African countries such as Benin, Guinea-Bissau, Mali, and Zambia, nations "long beset by poverty, authoritarianism, low administrative capacity, and ethnolinguistic divisions" (van de Walle 2002, 66).

Many unanticipated democratic transitions have been preceded by significant political instability in the form of coups and leadership transitions as well as contemporaneous uncer-

\footnotetext{
${ }^{1}$ For an overview, see, e.g., Przeworski, Alvarez, Cheibub \& Limongi (2000). Scholars have also examined other factors such as geographical endowments, colonial and legal legacies, cultural and religious practices, and ethnic fractionalization.
} 
tainty over the likely results of these changes. One illustrative case is Portugal. A military coup ousted the Estado Novo in April 1974. Incoming officers replaced political elites and called for elections, but were slow to retract themselves from power. A host of military and popular mobilizations put the elections in jeopardy, and five provisional governments cycled through office. The provisional period witnessed the nationalization of banks and insurance companies and an attack on traditional landowners through the redistribution of more than a million hectares of land in favor of workers. During this period, "the military did not serve the interests of the rich" but rather "acted primarily in defense of its own organizational interests" (Bermeo 2010, 1139-40). Only after an attempted left-wing military coup in November 1975 did moderate military officers move concertedly to hand power to civilians. In short, democratization in Portugal was hardly a sure bet. Furthermore, commonly cited factors such as income per capita and inequality were not only not determinative of the ultimate outcome, but instead played little role at all (Bermeo 2010).

Political instability and concomitant uncertainty have prevailed in numerous other surprising democratic transitions. Colombia's 1958 transition occurred on the coattails of a major civil war followed by erratic military rule and a military coup. Venezuela's 1959 transition transpired after a military coup displaced another military dictator, giving way to high-level conflict and purges within the military hierarchy and a provisional government. Guinea-Bissau's transitions in 2000 and 2004 were preceded by military coups and extremely high overturn in the upper echelons of government. The same is true of Thailand's transitions to democracy in 1975, 1979, and 1992, Turkey's transition in 1983, and several of Pakistan's transitions.

We do not contend that elite uncertainty over outcomes under autocracy can help explain all cases of democratic transition that remain puzzling in important respects. But evidence suggests that it operates in at least some of these cases, and that it can serve as a generalizable mechanism supportive of democratization. Section 5 discusses a range of cases in which the mechanism we propose has operated. 


\section{Models of Politics Under Dictatorship}

We build on a growing literature of formal models of nondemocratic politics (Gehlbach, Sonin \& Svolik 2016). These models often focus on endemic commitment problems in autocracies: because of a lack of a credible arbiter to enforce agreements, an authoritarian leader has incentives to renege on promises to his supporters once installed in power (Boix \& Svolik 2013, Gehlbach \& Keefer 2011, Myerson 2008). In Gehlbach \& Keefer (2011) for instance, authoritarian leaders have incentives to encourage economic elites to invest in the economy, but later to expropriate the fruits of these investments. These models then explore how authoritarian institutions or insider coalitions emerge to solve these commitment problems. Myerson (2008), for example, explores how autocratic leaders have incentives to create constitutional checks giving his supporters the ability to coordinate on overthrowing him should he renege on his promises.

Information asymmetries, of course, do not exclusively plague interactions between authoritarian rulers and political insiders. A host of recent formal models focus on information asymmetries between dictators and citizens. Among them, models of pseudo-democratic openings highlight how such information asymmetries may drive the choice to conduct elections under dictatorship (e.g., Miller 2013, Simpser 2013).

At the same time, models of the dynamics of power between authoritarian rulers and elite insiders are not always driven by information asymmetries tied to adverse selection, but also by moral hazard considerations. For instance, Svolik (2009) builds a model of endogenous balance of power among authoritarian elites in which the ruling coalition has imperfect information about the dictator's actions, and in particular whether the dictator is opportunistically jockeying to grab more power. This moral hazard problem then gives rise to established versus contested dictatorships depending on whether elites can credibly challenge the ruler.

Distinct from these other important contributions, we analyze information asymmetries between authoritarian actors and economic elites that derive from imperfect information 
about authoritarian actors' types. In particular, we explore the consequences of information asymmetries between economic elites and "dictator candidates" when commitment problems are prevalent, and model the dictator selection process that takes place in the run-up to a new regime equilibrium. This second step enables us to examine how commitment problems not only shape dynamics under authoritarian rule, but also the decision by economic elites to forego dictatorship entirely when it is too unpredictable and instead cast their lot with democracy.

The underlying assumption in our model, which follows the consensus in the literature regarding commitment problems under authoritarianism, is that a dictator candidate cannot credibly commit ex-ante to economic elites to implement a policy once in office that deviates from his type. What we term as this "candidate's commitment problem" implies, for instance, that a potential autocrat cannot commit to redistribute the fruits of expropriation back to the economic elites in order to increase the likelihood of being installed in power. Consequently, installed autocrats implement policies that are fully aligned with their ideology or "type". It is therefore crucial for the elites to learn about the true identity of potential autocrats before selecting one. Elites, however, face a heterogeneous pool of potential autocrats. Individual potential autocrats - aware of elites' uncertainty - have incentives to persuade them of their faithful intentions through a signaling process. Whether potential autocrats are successful in their persuasion attempts, however, depends on the informational environment. The noisier the informational environment (e.g., due to the fractionalization of a powerful military that repeatedly intervenes in politics), the less potential autocrats will be able to send precise signals, and the less they will be able to persuade the elites that they will be a faithful type.

Importantly, our model is distinct from others in the literature in that it generates comparative statics around equilibrium from the variance of the distributions of our key variables, rather than the variables themselves. This original feature at the core of our model could potentially be integrated into other existing models to examine how predictions are 
influenced by the interpretation of elite uncertainty we offer here. Consider for instance the selectorate model of Bueno de Mesquita, Smith, Siverson \& Morrow (2003). Members of the winning coalition $W$ - the economic elites in our model - have some expectation about the odds of being members of the next winning coalition given the distribution of challengers' "affinity" to them. However, should the variance in this distribution increase, some members of the winning coalition may prefer an alternative institutional system with a larger winning coalition size relative to the selectorate (e.g., with $W / S \simeq 1 / 2$ as in a democracy). This differs from partial democratization from above in Bueno de Mesquita et al. (2003, 382-8), which in their model is driven by members of the winning coalition weakening the "loyalty norm" by increasing W.

\section{A Model of Elite Uncertainty Under Autocracy and Democratization}

We develop a formal game-theoretic model capturing the idea that elite uncertainty may induce economic elites to push for democratization. Related to Bayesian persuasion models (Kamenica \& Gentzkow 2011), we adapt and apply a noisy signaling model proposed by Cunningham \& de Barreda (2015) in which the sender's type is drawn from a continuous distribution and the receiver's action is binary $\left.\right|^{2}$

Model Setup There are two players in our model: the economic elites and a potential subsequent autocrat (a "dictator candidate"). The potential autocrat is defined by his type $\theta \in[0,1]$, which can be interpreted as his alignment with the interests of the economic elites. When $\theta=1$, the potential autocrat is fully aligned with the elites and will not expropriate

\footnotetext{
${ }^{2}$ This application is also similar to Caselli et al. (2014), although their model has a discrete distribution of sender's type. Differences in our application relative to Cunningham \& de Barreda (2015) include the distribution of the sender's type, the receiver's outside option, the functional form of the message cost, and the distribution of the noise.
} 
their wealth when he is in power. When $\theta=0$, he is not at all aligned with the elites and will have strong incentives to expropriate their wealth when he is in power. In other words, an autocrat's type directly maps onto policy choices.

Divergent preferences between potential autocrats and elites can arise due to pressure on potential autocrats from key non-elite allies such as the military or a desire to destroy economic elites as a rival threat to maintaining power. A host of literatures ranging from that on state autonomy (e.g., Trimberger 1978) to that on modernizing militaries (e.g., Huntington 1968, Janowitz 1977) and elite competition (e.g., Albertus 2015, Albertus \& Menaldo 2012, Ansell \& Samuels 2014) support the notion of varying overlap in interests between ruling political elites and powerful economic elites in society. One key implication from these contributions is that the degree of alignment is not easily shifted once a dictator is in power: a dictator's actions to forego the expropriation of economic elites while in office can directly contradict his ability to please other critical political allies or to gain valuable political autonomy when alignment with economic elites is low $\mathrm{S}^{3}$

The autocrat's type is a random variable privately known to the autocrat and drawn from a uniform distribution $F(\cdot)$ with density $f(\cdot)$ over $[\mu-b, \mu+b] \subseteq[0,1]$. The average type is $\mu$, and types are spread around the mean by a distance up to $b$, where $b=\left(3 \sigma_{\theta}^{2}\right)^{1 / 2}$ and $\sigma_{\theta}^{2}$ is the variance of the distribution. The average type $\mu$ has a real-world counterpart and may differ across contexts: economic elites may expect potential dictators to be on average more favorable in one country than in another $4^{4}$ We define the economic elites' uncertainty over the pool of potential subsequent autocrats as the variance in the distribution of types $5^{5}$

${ }^{3}$ For instance, other members of an autocrat's support coalition may be rivals to economic elites and willing to oust the autocrat if he does not destroy those rivals via expropriation. ${ }^{4}$ For instance, in the 1960s-1970s in Thailand, dictators were repeatedly drawn from the military, which did not overlap strongly with economic elites; in other cases such as Nigeria or contemporary China, dictators are repeatedly drawn from the economic elites.

${ }^{5}$ Increasing the variance in the distribution of types always pushes the bounds of the dis- 
Elite Uncertainty 1. Elite uncertainty over the pool of potential subsequent autocrats is defined as the variance in the distribution of types, $\sigma_{\theta}^{2}$.

The economic elites can either back the potential autocrat and install him in power $(a=1)$, or refuse to do so and push for democratization $(a=0)$. Without loss of generality, we assume that economic elites are strong enough so that democratization always occurs when they initiate it. The economic elites own the country's unit endowment. If they install the autocrat in power, they get to keep a share $\theta$ of their endowment. This implies that the dictator's policies once in office cannot deviate from his type. As discussed above, low institutional constraints enable dictators to seize part of the economic elites' assets (Albertus 2015), and the extent of this varies with the dictator's alignment with elites.

Although economic elites could, at some point, replace the autocrat if he turns out to be a low type, they cannot do so instantaneously or without first losing a share of their endowment. This is because expropriation overwhelmingly occurs early in a new dictator's tenure - typically within the first year of holding power - and also helps to stabilize autocratic rule (Albertus \& Menaldo 2012). Furthermore, expropriation often strikes with little prior warning. The Peruvian military dictator General Juan Velasco Alvarado, for instance, took pride in surprising economic elites, including some that financially supported the coup, stating on the first anniversary of his coup that "Some people expected very different things and were confident, as had been the custom, that we came to power for the sole purpose of calling elections and returning to them all their privileges. The people who thought that way were and are mistaken" (Davies \& Loveman 1997, 189). Economic elites, and especially large landowners, were caught off guard by the rapid pace of expropriation. Take Lucho Alcázar, a landowner in Junín, who recounted his expropriation vividly: "The agrarian reform came [to us] on November 28, 1973...It hit us like a bucket of cold water. I will never tribution outward: $\partial b / \partial \sigma_{\theta}^{2}=3 / 2\left(3 \sigma_{\theta}^{2}\right)^{1 / 2}>0$. Our interpretation of the dictator's type implies some restrictions on the variance in the distribution of types, which cannot be too large: $\sigma_{\theta}^{2} \leq \min \left\{\mu^{2} / 3,(1-\mu)^{2} / 3\right\}$. This is without loss of generality. 
forget it because it was most unpleasant..." (Mayer 2009, 90). Velasco, like many dictators expropriating economic elites, deliberately moved stealthily as a way to surprise elites and more effectively target them while reducing collective resistance (McClintock 1983).

The main implication for the model here is that economic elites who draw a low type autocrat and want to draw another one will be operating with a low $\theta$ when they do so. Because their ability to successfully remove the current autocrat is likely to be dependent upon their wealth (Acemoglu \& Robinson 2008), a bad draw in the first round increases the chances that they will be stuck in an equilibrium with a low type, making their decision about who to back today of first-order importance ${ }^{6}$ For this reason, a static game appropriately captures the key elements of the situation at hand. Nonetheless, the main comparative statics of the model all hold - indeed, they are reinforced - in a dynamic setting.7

If elites do not install the potential autocrat but instead push for democratization, they have to pay a tax rate $T \in[0,1]$ on their endowment. We denote the expected tax rate as $\mathbb{E}[T]=\widetilde{T}$ to reflect elite uncertainty over what the ultimate tax rate will be $\left.\right|^{8}$ Their expected payoff under democracy is therefore $1-\widetilde{T}$. Of course, "institutionalized uncertainty" under democracy implies that outcomes are hardly a sure bet; nonetheless, democratic institutions reduce key elements of uncertainty relative to dictatorship (Przeworski 1991, North 1990). Following most of the literature on this topic, we assume that both the elites and the potential autocrat are risk-neutral (i.e., their utility is linear in payoffs).

The expected tax rate does not impact the main model predictions; it simply shifts up or down the willingness of economic elites to live under democracy. Several authors have demonstrated that some democracies are very favorable to economic elites whereas others

${ }^{6}$ We formally illustrate the implications of costly autocrat replacement in Appendix $\mathrm{H}$. ${ }^{7}$ Appendix I formally demonstrates that the model implications hold with an arbitrary number of periods of play. Multiple periods increase the odds that elites will have a bad draw. ${ }^{8}$ For instance, suppose that the tax rate rate is low at $T=\underline{T}$ with probability $p$, and high at $T=\bar{T}$ with probability $1-p$. Then, $\widetilde{T}=\bar{T}-p(\bar{T}-\underline{T})$. 
are much less so (e.g., Acemoglu \& Robinson 2008, Albertus \& Menaldo 2014). These authors also demonstrate, however, that economic elites that initiate democracy often have an advantage in designing democratic institutions, which decreases their uncertainty over the level of taxation, as well as the expected rate of taxation itself. Consider Chile. The outgoing Pinochet regime used the results of a popular referendum on the eve of democratization to tailor-make a binomial electoral system that would systematically over-represent their interests in Congress (Rahat \& Sznajder 1998). This was coupled with holdover senator seats for the military. The result was broad fiscal continuity across the transition: while corporate tax rates rose slightly in the two decades following democratization, personal income taxes actually decreased.

The potential autocrat gets a payoff of zero under democracy and of one if he is installed in power. For simplicity, the autocrat's payoff is independent of his type. Autocrats care chiefly about holding power. If an autocrat is not aligned with economic elites and expropriates them, this serves principally to shore up the autocrat's power by providing the fruits of expropriation to a supporting coalition (Albertus \& Menaldo 2012).

Uncertainty in the pool of potential autocrats We begin by providing the intuition for why uncertainty in the pool of potential autocrats creates incentives for the economic elites to push for democratization. Suppose that the economic elites perfectly observe the autocrat's type once its value is realized, and then decide whether or not to install him in power. Their decision rule here is simply to install the autocrat in power as long as they are better off under autocracy than under democracy, i.e., whenever $\theta>1-\widetilde{T}$. Therefore, the likelihood of democratization is given by: ${ }^{9}$

$$
\operatorname{Pr}(\text { democracy })=\operatorname{Pr}(\theta \leq 1-\widetilde{T})=\frac{1}{2}-\frac{\nu}{2 b},
$$

where $\nu=\mu-(1-\widetilde{T})$ is the expected relative benefit for the elites of autocracy over ${ }^{9} \operatorname{Pr}(\theta \leq 1-\widetilde{T})=F(1-\widetilde{T})=[(1-\widetilde{T})-(\mu-b)] /[\mu+b-(\mu-b)]=1 / 2-[\mu-(1-\widetilde{T})] / 2 b$. 
democracy 10 This already generates an intuition for why higher uncertainty in the pool of potential autocrats induces elites to support democratization more often. Because the elites democratize whenever the autocrat's type is below the threshold $1-\widetilde{T}$, a higher variance in the distribution of autocrat types increases the density of types that are rejected by the elites. We illustrate this point in Figure 1, where we plot the density of types for two levels of uncertainty. While both distributions have the same average $(\mu=0.5)$, density $f^{1}$ has a lower bound of 0.3 , and density $f^{2}$ has a lower bound of 0.1 , so that there is more uncertainty over the types of autocrats in the second pool than in the first one. As a result, the density below the threshold is larger in the case of the second pool (density $f^{2}$ ) than in the case of the first pool (density $f^{1}$ ). Note that the area to the left of the threshold is equal to the probability of democratization (Equation 1).

[Figure 1 about here]

Uncertainty in the informational environment We now introduce asymmetric information. Consider the case in which the elites do not observe the potential autocrat's type. Rather, it is his private information. The potential autocrat knows how the elites form their decision, so he has incentives to try to persuade them that he is more closely aligned with their interests than he actually is. Before the elites make their decision, the autocrat sends them a message $m$ to signal his type. Sending a higher message than one's type requires some costly effort, where the effort is the difference between the message and the type, $m-\theta$.

${ }^{10}$ We focus on the interesting case in which the elites generally prefer autocracy, and in which democratization has a positive probability $(0<\nu \leq b)$. Should the elites make their decision prior to observing the realization of the autocrat's type, they would apply the rule $\mu>1-\widetilde{T}$, implying a probability of democratization of zero. In many cases, evidence suggests that elites seek to learn their options before deciding whether to support continued dictatorship (see, e.g., Gilbert 1977, Palacios 2006). 
The cost of effort is represented by a strictly convex function $C(\cdot)$, with $C^{\prime}(0)=0$. More specifically, $C(\cdot)$ is a quadratic cost function so that the slope of the marginal cost of effort is constant at $C^{\prime \prime}(\cdot)=c$, with $C(m-\theta)=\left[c(m-\theta)^{2}\right] / 2$. Mathematically, convexity makes manipulating messages relatively more costly for lower types than it is for higher types. This will allow the autocrat's optimal messaging strategy to have monotone comparative statics, i.e., to be increasing in type (Ashworth \& Bueno de Mesquita 2006).

There are several possible reasons for why it requires costly effort to send a higher message than one's type. For example, it should be relatively cheaper and easier for a potential autocrat who is sociologically and ideologically closer to the economic elites to formulate credible promises. This is in part because such a candidate often conforms to the norms of conduct and behavior of economic elites. Take the case of Peru: the so-called "forty families" that dominated the economy often invited would-be military rulers to socialize with them at Lima's most exclusive social club in an effort to evaluate whether these candidates shared their manners, accents, sympathies, and, by extension, visions for policymaking (Gilbert 1977). Some candidates easily passed this "sniff test" and ensured elites of their fidelity whereas others floundered. Those that struggled had to double down and spend time learning how to fit in amongst elites (which often failed), or had to compromise their autonomy and find allies to act as emissaries to elites. Another strategy could be to compromise with economic elites on future behavior. Yet this could generate resistance from core supporters, and due to the "candidate's commitment problem," such compromises would not very credible.

Another potential cost to sending an especially high message is that messages could also be observed by an autocrat's immediate support coalition (e.g., coup co-conspirators or military insiders). If that support coalition is distinct from economic elites, its members may begin to doubt the trustworthiness of an autocrat who curries favor with economic elites. Consequently, the autocrat may have to cede them greater power or rents in an effort to credibly signal his true type and shore up insider support. 
Economic elites observe the autocrat's message imperfectly. They receive a signal $s=$ $m+u$, where $u$ is a noise drawn from a normal distribution centered around zero with a variance $\sigma_{u}^{2}$ We denote the density of the noise as $g(\cdot)$. This noisy environment is intended to capture the uncertainty that surrounds moments of leadership change toward a new dictator or a democratic regime. For instance, in cases such as Thailand or Portugal in the 1970s, the recurrence of coups and the division of the military into multiple factions makes it harder for the elites to extract accurate information about the identity and likely policies of potential autocratic successors. A host of would-be autocrats in these cases promised different policies to different groups in order to build larger coup coalitions.

We define the economic elites' uncertainty over the informational environment as the variance in the distribution of the noise:

Elite Uncertainty 2. Elite uncertainty over the informational environment is defined as the variance in the distribution of the noise, $\sigma_{u}^{2}$.

Model equilibrium Upon receiving a signal $s$, the elites update their belief about the autocrat's type following Bayes' rule. Their updated belief is a function of the signal they receive and the strategy of the autocrat. It has density $f(\theta \mid s, m)$. An equilibrium is a pure strategy for the autocrat $m:[\mu-b, \mu+b] \rightarrow \mathbb{R}$, and a pure strategy for the elites $a: \mathbb{R} \rightarrow\{0,1\}$, such that each player's strategy maximizes their expected utility given the other player's strategy and the beliefs of the economic elites are consistent with Bayes' rule:

$$
\left\{\begin{array}{l}
\forall \theta \in[\mu-b, \mu+b], \quad m(\theta) \in \arg \max \int a(m+u) g(u) \mathrm{d} u-C(m, \theta) \\
a(s)=1 \Longleftrightarrow \int \theta f(\theta \mid s, m(\cdot)) \mathrm{d} \theta \geq 1-\widetilde{T}
\end{array}\right.
$$

Under the assumption that the cost function is sufficiently convex, we can characterize

\footnotetext{
${ }^{11}$ Besides being realistic, the noise eliminates the possibility of pooling and semi-separating equilibria, which enables us to derive comparative statics around the equilibrium.
} 
the equilibrium as follows. 12

Proposition 1. There exists a unique equilibrium $\left(m^{*}(\cdot), a^{*}(\cdot)\right)$ characterized by a threshold $k^{*}$ such that:

(a) The economic elites use a threshold rule: $a^{*}(s)=1$ if $s \geq k^{*}$, and $a^{*}(s)=0$ if $s<$ $k^{*}$, where the equilibrium threshold $k^{*}$ is such that the elites are indifferent between autocracy and democracy whenever they receive a signal exactly at this threshold, i.e., $\mathbb{E}\left[\theta \mid s=k^{*}\right]=1-\widetilde{T}$.

(b) The autocrat's equilibrium strategy $m^{*}(\theta)$ is increasing in his type.

(c) The autocrat's equilibrium strategy solves: $g\left(k^{*}-m^{*}(\theta)\right)=C^{\prime}\left(m^{*}(\theta)-\theta\right)$.

Proof. See appendix A.

Figure 2a displays the incentives faced by the autocrat when choosing a message level for a given threshold $k$. The x-axis represents the autocrat's type $\theta$ as well as message levels $m$. The solid curve represents the autocrat's marginal benefit of a message, and the straight lines represent the autocrat's marginal cost of effort. Intuitively, the level of the marginal benefit curve corresponds to the marginal increase in the probability that the elites receive a signal that is above the threshold, and therefore select the autocrat. By construction, the threshold always corresponds to the peak of the distribution $g(k-m)$, as the distribution of the noise $g(\cdot)$ is centered around zero.

[Figure 2 about here]

It is clear from Figure 2a why the messaging strategy is increasing in the autocrat's type, as indicated by part (b) of Proposition 1. Increasing the autocrat's type does not

${ }^{12}$ More specifically, we assume that the slope of the marginal cost curve is high enough with $c>\mathrm{e}^{-1 / 2} / \sigma_{u}^{2} \sqrt{2 \pi}$. See appendix A for more details. The characterization of the equilibrium follows Cunningham \& de Barreda's (2015) Proposition 2. 
change the marginal probability that the signal received by the elites will be above the threshold. However, because the cost of effort is convex, higher types find it relatively less costly to send higher messages. Graphically, increasing the type from $\theta_{1}$ to $\theta_{2}$ shifts the autocrat's marginal cost curve to the right from the dotted line to the dashed line. This in turn increases the equilibrium level of the message because the dashed marginal cost curve crosses the solid marginal benefit curve at higher message levels: part (c) of Proposition 1 requires the equilibrium message to be such that the marginal cost of effort equals the marginal increase in the probability of being selected 13

Figure 2b provides the intuition for why higher uncertainty in the informational environment - captured by higher variance in the distribution of the noise - increases the likelihood of democratization. When the variance in the distribution of the noise is relatively small, the marginal benefit curve is concentrated around the threshold (solid curve). On the figure, the optimal message for an autocrat of type $\theta_{1}$ is exactly equal to the threshold $k=0.5$. As a result, the elites accept this autocrat half of the time: because the elites receive a signal $s\left(\theta_{1}\right)=m\left(\theta_{1}\right)+u=k+u$ from this autocrat and the distribution of the noise is symmetric around zero, the probability that the signal is above $k$ is equal to $1 / 2$.

Now suppose that the variance in the distribution of the noise increases, so that the marginal benefit curve is less concentrated around the threshold (dashed curve). Then, the autocrat of type $\theta_{1}$ has less incentives to exert effort in sending a higher message because the marginal probability that the signal is above the threshold has declined: instead of a marginal benefit of about 1.6, a message level of 0.5 now only provides a marginal benefit of about 1 with a marginal cost still equal to 1.6. Consequently, following part (c) of Proposition 1 , the autocrat decreases his message level until the marginal cost of the message equals its marginal benefit (i.e., where the dashed curve and the dotted line cross). The autocrat's

\footnotetext{
${ }^{13}$ This figure also shows why we need to assume the cost function to be sufficiently convex: the marginal cost curve needs to be steep enough to cross the marginal benefit curve only once, ensuring that the equilibrium message is unique.
} 
optimal message level is now about 0.43 instead of the 0.5 that it was before the variance in the distribution of the noise increased. Now, only an autocrat of type $\theta_{3}$ would find it optimal to send a message level of 0.5 , with $\theta_{1}<\theta_{3}$. The elites end up selecting the autocrat of type $\theta_{1}$ less often than before: while they were effectively selecting any type of autocrat $\theta \in\left[\theta_{1}, 1\right]$ more than half of the time, they now only do so for the types $\theta \in\left[\theta_{3}, 1\right] .^{14}$

Probability of democratization Now that we have characterized the equilibrium, we can derive the probability of democratization. Given a threshold $k$, the probability of democratization is the probability that the signal received by the elites is below the threshold given some realization of the noise, $\operatorname{Pr}(m+u \leq k \mid k, u)$. We can compute this probability explicitly by first deriving the density of messages sent by potential autocrats. This derivation can be found in Appendix $\mathrm{B}$ along with a graphical interpretation of the shape of the density of messages. The probability of democratization for a given threshold can then be written as:

$$
\operatorname{Pr}(\text { democracy } ; k)=\frac{1}{2}-\frac{\nu}{2 b}+\frac{k-(1-\widetilde{T})}{2 b}-\frac{1}{2 b c} \int[g(u)]^{2} \mathrm{~d} u \text {. }
$$

Proof. See appendix C.

The first two terms represent the probability of democratization when there is no information asymmetry (see Equation 1). The third term corresponds to the democratization that arises when the elites set a higher threshold: for each unit of the threshold above the

${ }^{14}$ Incentives to send higher messages may increase for extreme types. For instance, the marginal benefit of higher messages increases for an autocrat of type $\theta_{2}$. Formally, this is not the case for types that send messages not too far from the threshold (i.e., those for which $(k-m)^{2}<\sigma_{u}^{2}$, because $\left.\partial g(k-m) / \partial \sigma_{u}^{2}=\left[g(k-m) / 2 \sigma_{u}^{4}\right]\left[(k-m)^{2}-\sigma_{u}^{2}\right]\right)$. This is not restrictive because comparative statics around the equilibrium are driven by the types sending messages at the threshold. 
level $1-\widetilde{T}$, a density of $1 / 2 b$ of types of autocrats is rejected. The last term corresponds to the precision of the noise. More precisely, the expected density $\mathbb{E}[g(u)]$ can be interpreted as the concentration of the distribution of the noise. As illustrated in Figure $2 \mathrm{~b}$, the less precise the signal, the less the marginal benefit curve of the autocrat is concentrated around the threshold, and the less types around the threshold have incentives to exert effort to increase their message level. As a result, when the environment becomes noisier (i.e., the last term decreases), signals are on average lower and less types are selected, leading to a higher likelihood of democratization:

$$
\frac{\partial \operatorname{Pr}(\text { democracy } ; k)}{\partial \sigma_{u}^{2}}>0 .
$$

Proof. See appendix D.

The last step is to compute the equilibrium threshold $k^{*}$. Recall that $k^{*}$ is such that the elites must be indifferent ex ante between selecting the autocrat and pushing for democratization whenever they observe a signal exactly at the threshold, i.e. when $\mathbb{E}\left[\theta \mid s=k^{*}\right]=1-\widetilde{T}$. We can write $k^{*}$ as 15

$$
k^{*}=1-\widetilde{T}-\frac{1}{c} \int u g^{\prime}(u) g(u) \mathrm{d} u>1-\widetilde{T} .
$$

Proof. See appendix E.

Note that $u g^{\prime}(u)<0$ because of the symmetry of $g(\cdot)$ around zero. Therefore, $k^{*}>1-\widetilde{T}$. That is, the equilibrium threshold is higher than the type $\bar{\theta}=1-\widetilde{T}$ that would actually make elites indifferent between autocracy and democracy. This is because the elites know that potential autocrats have incentives to send higher messages than their type. Hence, they know that a type $\bar{\theta}$ must have sent a message above $1-\widetilde{T}$. It follows that the stronger the

${ }^{15} \mathrm{~A}$ closed form solution to $k^{*}$ requires the density of the noise to be bounded on some support symmetric around zero, implying a truncated distribution for $u$. We show in appendix $\mathrm{G}$ that the results holds under such a distribution. 
incentives for the autocrats to send higher messages, the higher elites will set the threshold $k^{*}$, and the less types will be selected. Conversely, the weaker the incentives for the autocrats to send higher messages - such as in a very noisy informational environment - the lower the threshold and the more types are selected, leading to a lower likelihood of democratization. We provide graphical intuition for how the elites set the equilibrium threshold in Appendix F

This effect goes in the opposite direction to the other (direct) effect of uncertainty in the informational environment illustrated in Figure 2b. Importantly, however, we show below that this indirect effect is systematically dominated by the direct effect. Therefore, higher uncertainty in the informational increases the likelihood of democratization. Combining Equation 2 together with Equation 4, we can provide the expression for the equilibrium probability of democratization. 16

Proposition 2. The equilibrium probability of democratization is:

$$
\operatorname{Pr}(\text { democracy })=\frac{1}{2}-\frac{\nu}{2 b}-\frac{1}{2 b c}\left[\int[g(u)]^{2} d u+\int u g^{\prime}(u) g(u) d u\right] .
$$

The probability of democratization is composed of three groups of terms. The first two terms represent the probability of democratization when there is no information asymmetry (see Equation 1). The first term in brackets represents the direct effect of uncertainty in the informational environment: when the environment becomes noisier, potential autocrats that are close to the threshold have less incentives to exert effort in sending higher messages, leading to lower signals and thus a smaller likelihood of being selected by elites. The second term in brackets represents an opposing effect: when the environment becomes noisier, the elites, aware of the autocrats' behavior, adjust the threshold down, leading to more types being admitted. However, this second-order effect is systematically dominated: using

${ }^{16}$ This proposition follows the steps of the derivations in Cunningham \& de Barreda's (2015) Theorem 7 . 
integration by parts, the terms in brackets in equation 5 can be written as $-\int u g^{\prime}(u) g(u) \mathrm{d} u$, which is strictly positive because $u g^{\prime}(u)<0$ as the distribution is symmetric around zero.

Building on our previous results, we can show that increasing elites' uncertainty over the pool of potential autocrats as well as over the informational environment increases the likelihood of democratization:

\section{Proposition 3.}

$$
\frac{\partial \operatorname{Pr}(\text { democracy })}{\partial \sigma_{\theta}^{2}}>0 \text { and } \frac{\partial \operatorname{Pr}(\text { democracy })}{\partial \sigma_{u}^{2}}>0 .
$$

Proof. See appendix G.

We illustrate Proposition 3 in Figure 3, where the x-axis represents the variance in the distribution of the noise $\sigma_{u}^{2}$. We display the probability of democratization for a low (solid curve) and a high (dashed curve) level of variance in the pool of potential autocrats $\sigma_{\theta}^{2}$. The probability of democratic transition is increasing in $\sigma_{u}^{2}$. Moreover, this probability shifts up when the variance in the pool of potential autocrats is higher.

[Figure 3 about here]

\section{The Scope of the Uncertainty Mechanism for De- mocratization}

How common does the uncertainty mechanism that we propose operate in democratization? This section attempts to bound the likely generalizability of the mechanism, as well as to provide an illustrative overview of a number of cases in which it has operated.

The model highlights two chief mechanisms that underpin economic elite support of democratization: uncertainty in the pool of potential dictators and uncertainty in the informational environment. When uncertainty along these dimensions is high, economic elites will have incentives to lead the charge toward democracy. Which cases of democratization have been characterized by these circumstances, such that elite uncertainty may have been 
a contributing factor underpinning democratization?

\subsection{Cases of Elite Uncertainty and Democratic Transition}

Several key pieces of data aid in generating bounds for the likely applicability of the theory. First, given that elites in our model are the key actors pushing for democratization, transitions that occur "from below" via revolutions or popular movements are unlikely to capture the dynamics we highlight. By contrast, transitions "from above", especially those that involve elites imposing institutions on a new democracy in order to protect their core interests, are more likely candidates for our theory. Cases of democratization preceded by coups and counter-coups, political purges, and major cabinet reshuffles are also candidates for our theory, since these factors can generate uncertainty in the informational environment facing elites. On the other hand, our theory is less likely to be operative in transitions from single party rule. Regularized succession in single parties reduces (though does not entirely eliminate) uncertainty - as well as the stakes - regarding subsequent dictators. Upcoming leaders are often groomed for years ahead of time in the public eye, and certainly with the blessing of the party.

Table 1 displays a set of cases of democratic transition in which our uncertainty mechanism is most likely to have operated. Data on regime transitions are taken from Cheibub, Gandhi \& Vreeland (2010). These authors, following Przeworski et al. (2000), code regimes as either democracies or dictatorships. Democracies are regimes in which (1) the chief executive is elected; (2) the legislature is elected; (3) there is more than one political party; and (4) an incumbent has lost power and transferred it peacefully to a new leader. There were 121 transitions from 1900-2008. Table 1 displays the cases that witnessed transitions from above from non-single party rule. Transitions from above are coded when two conditions are met. First, there is not a successful revolutionary movement observed in the year prior to transition (see Goldstone 1998). Elites are typically weak in the context of revolutionary 
transitions, and are therefore unlikely to be the key actors pushing for transition ${ }^{17}$ Second, when elites are able to impose an autocratic constitution on the incoming democratic regime. Many new democracies inherit constitutions and an associate institutional architecture from the prior autocratic regime; these are circumstances that capture a strong, organized elites able to impose their preferences on a new democracy (Albertus \& Menaldo 2014). There are 61 cases during this period that meet these criteria.

For each transition case, Table 1 displays the number of coups, major cabinet changes (either the naming of a new premier or the replacement of $50 \%$ or more of cabinet posts with new ministers), and political purges in the three years prior to the transition year. The presence of such changes should, according to our theory, make the information environment more uncertain. Data on these variables are taken from Banks \& Wilson (2015).

[Table 1 about here]

Colombia. There is evidence for our uncertainty mechanism in a number of the cases displayed in Table1. In Colombia, for instance, Rojas Pinilla seized power in 1953 and staffed his cabinet with moderate Conservatives. But his rule became more arbitrary over time as he came to rely on an unstable coalition of factory workers, the popular masses, and the military rather than the traditional alliance of landowners, merchants, and bankers (Palacios 2006, 132). Facing an increasingly autonomous military and unpredictable military ruler, elites reached across the Conservative-Liberal divide to oust him in 1958 while simultaneously forging a collusive democratic pact via the National Front to safeguard their core interests (Palacios 2006).

Thailand. In Thailand, elites have wrestled over decades to muster a notoriously frag-

${ }^{17}$ Table 1 includes two transitions preceded by revolution as coded by Goldstone (1998): Colombia in 1958 and Venezuela in 1959. These revolutionary events did not preclude transitions from above. 
mented military in support of suppressing the ascendancy of popular classes. Yet military rulers, once in power, have repeatedly attempted to extend their rule arbitrarily and implement policies that alienate elites such as the Tax Increase Bill of 1970. Consequently, dictatorship has collapsed multiple times as nascent economic elites and communal elites (most especially the King) withdrew their support from the military and instead attempted to craft a form of oligarchic democracy in which they could effectively compete electorally (Slater 2010, 248-52).

Pakistan. Economic elites in Pakistan have had a similarly turbulent relationship with the military, witnessed most recently in General Musharraf's ousting in 2008. Musharraf threatened elites by granting the military increasing monopoly power over state patronage and business opportunities from privatization, and his efforts to extend his rule and cut down the judiciary were the final straw for elites uncertain about how they would fare under an increasingly unchecked military in coming years.

Peru. Elite uncertainty also played a key role in Peru's transition to democracy in 1980. When a clash between Finance Minister Silva Ruete and Minister of Industry Gabriel Lanata led to the latter being pushed out in 1978 after a decade of autonomous and shifting military rule, the powerful export and industry confederations increased opposition to the regime, given that Lanata's presence in the cabinet was considered a "guarantee to the private sector" (Conaghan \& Malloy 1995, 79). They then worked hard with political parties in a constituent assembly to win constitutional guarantees to private property upon democratization in 1980.

Central African Republic and Madagascar. In other cases, influential economic elites that become disenchanted with uncertainty under dictatorship and consequently push for democracy are actually members of the dictator's cabinet. Arriola (2009, 1347), for instance, argues that in many African countries, "leaders have used ministerial appointments to the cabinet as an instrument for managing elite relations," empowering elites in their support coalition. In the run-up to transitions such as the Central African Republic and Madagascar in 1993, autocratic rulers' attempts to increase their power over elites via shuf- 
fling cabinet positions in their governments backfired: disaffected former members of these regimes no longer trusted their rulers, and they mobilized collaborators from outside the patronage system. Democratization occurred in the absence of any significant anti-government demonstrations or strikes and resulted in the reemergence of powerful figures from the previous regime: "Africa's new governments [in the 1990s] were often composed of individuals who had collaborated with the previous regime in the not so distant past and who possessed no viable representative organization of their own" (Bratton \& Van de Walle 1997, 258).

South Africa. Though elite uncertainty was hardly the only factor supporting a transition in South Africa, key business leaders of the Consultative Business Movement who feared an unforeseeable and bloody future under an increasingly militaristic and narrow apartheid regime helped to spur transition by reaching out to the ANC and shaping their policy platforms. ${ }^{18}$ The chairman of Anglo American, Gavin Relly, for instance, famously met with the ANC's exiled leader Oliver Tambo in 1985 in a move that unnerved the government and helped paved the way for businesses and the ANC to collaborate in the transition.

\subsection{The Uncertainty Mechanism and Democratization in Bolivia}

Elite uncertainty about dictatorship and a consequent preference for more predictable democratic rule was also a key factor in Bolivia's tepid first steps toward democracy in 1979 followed by its transition to stable democratic rule in 1982. This section, while not a definitive test of the theory, instead illustrates how the two chief mechanisms in the model that underpin elite support of democratization - uncertainty in the pool of potential dictators and uncertainty in the informational environment - manifest themselves concretely in the jockeying between elites and dictator candidates.

${ }^{18}$ South Africa fails Cheibub, Gandhi \& Vreeland's (2010) "alternation rule" and is therefore not listed in Table1. Other major democracy measures code South Africa as democratic. 


\subsubsection{The Formation of Economic Elites and the Rise of Uncertainty in the Pool of Dictator Candidates}

From the 1960s through the 1970s, Bolivia experienced a large number of coups and countercoups that empowered dictators from across the ideological spectrum. This increased the uncertainty in the pool of potential autocrats from the point of view of newly forming economic elites. Bolivia's 1952 revolution yielded stable single-party rule under the Movimiento Nacionalista Revolucionario (MNR) for over a decade. The MNR directly attacked economic elites for the first time, nationalizing the tin mines and implementing massive land reform. The MNR was overthrown in a coup by René Barrientos and Alfredo Ovando in 1964.

Barrientos' death five years later gave way to several short-lived military coups. Ovando toppled Barrientos' vice president to seize power himself and then tacked left. The military began to split between those supporting Ovando and his declared leftist principles (e.g., General Torres) and those supporting a more conservative and pro-U.S. stance (e.g., General Miranda). A right-wing junta ousted Ovando in October 1970 but was beaten back violently in the streets by General Torres the next day. Torres was even farther to the left than Ovando. He doubled down on land reform and called a People's Assembly that was to effectively act as a Parliament. Torres in turn was overthrown a year later by another coup that empowered the right-leaning General Hugo Banzer with elite support.

Structural changes in the Bolivian economy cultivated a new set of economic elites beginning in the late 1960s and early 1970s that supported Banzer. Twenty years of economic and social investments under the MNR and Barrientos were finally reaping benefits. A price spike in oil and minerals further stimulated domestic and foreign investment. The three most powerful new groups of economic elites that emerged in the revamped private sector were the Confederación de Empresarios Privados de Bolivia (CEPB), which was a peak association for business interest groups and the major rival to the powerful Bolivian Workers' Union (COB), the Asociación Nacional de Mineros Medianos, which represented mediumsized mine owners, and organizations such as the Cámara Agropecuaria del Oriente, which 
represented growing agro- and agro-industrial enterprises in the rapidly emergent Santa Cruz department (Conaghan \& Malloy 1995, 74).

\subsubsection{Dictatorship Continues: Successfully Signaling Type}

Economic elites represented by these elite groups saw themselves in Banzer and trusted him to further their interests against the left. Banzer was from Santa Cruz and had German settler roots. He was one of Santa Cruz's agrarian elites: he owned a large hacienda in the department, and his brother owned large tracts of land in Santa Cruz and throughout the eastern lowlands for cultivating cotton (Schulte-Bockholt 2006, 77). Furthermore, Banzer's actions in the lead-up to his successful 1971 coup sent a clear, costly signal to his elite backers. Banzer's support for Ovando's ouster in 1970 cost him his position as director of the National Military Academy. His unsuccessful early 1971 coup attempt against Torres - who was threatening the extension of massive land expropriation to Santa Cruz province - resulted in over six months of exile. Banzer's second coup attempt later in 1971 was therefore launched from Santa Cruz and had strong backing from the region's economic elites (Schulte-Bockholt 2006, 77).

Importantly, Banzer's ability to signal his type to economic elites led to their choice of him as president over other coup co-conspirators - and also over democracy. Colonel Andres Selich's ranger regiment in Santa Cruz and General Mendieta's Seventh Division in Cochabamba were also key in toppling Torres. Indeed, these leaders announced a three-man junta from Cochabamba while rebel-controlled radio simultaneously announced a Banzer presidency from Santa Cruz. Yet Selich and Mendieta had few established ties with economic elites and had not spent time crafting appeals to elites. A conference of rebel leaders consequently turned the tide for Banzer, who was seen as a centralizing figure and the key conduit to support from private business (CIA 1971, 3-5).

Once in office, Banzer suspended the $\mathrm{COB}$ and implemented a raft of policies benefiting middle-size mine owners, business owners, and nascent commercial agricultural elites in Santa Cruz. Nonetheless, he retained political power directly within the military. 


\subsubsection{Uncertainty in the Pool of Dictator Candidates and Unsuccessful Signal- ing}

Pressure from labor strikes and military disenchantment with failed territorial negotiations with Chile built on Banzer in the mid-late 1970s. Furthermore, there was growing discomfort among business leaders about their exclusion from direct economic policy-making (Conaghan \& Malloy 1995, 79). This raised the stakes in the event that Banzer was replaced or embarked on a radical policy shift to cauterize popular or military opposition.

Take the example of Augusto Cuadros Sánchez, who in 1975 was the General Manager of the Industrial Finance Bank in Oruro. The Industrial Finance Bank was owned by the private small mining sector in the mineral-rich Oruro region. Like a growing number of economic elites and military players, Cuadros wanted Banzer overthrown by an even more reliable military man who gave elites a direct hand in economic policy-making. General Eladio Sánchez Gironda approached him, asking if he could deliver the support of small miners if Sánchez Gironda was to topple Banzer. In return, Cuadros could be sure of Sánchez 's support of Oruro's private miners. Cuadros agreed. Yet when Sánchez Gironda subsequently called a decisive coup-planning meeting with co-conspirators, Cuadros was floored that they spoke merely of how posts would be distributed in a new government and promotions doled out; there was no talk of the programs Sánchez Gironda would implement. Cuadros was "at first uneasy, then disgusted, and finally sorry that I had involved myself with people of that ilk... I decided never again to conspire with military men or associate with them politically" (Cuadros Sánchez 2004, 50) 19 His decision was only hardened after he was thrown into prison for conspiracy and came into contact with a host of captains, lieutenants, and sublieutenants that were failed coup conspirators, raising his awareness of what military men were willing to risk to climb the ranks (Cuadros Sánchez 2004, 52).

Meanwhile, Sánchez Gironda's mixed signals to different audiences backfired. A sufficient number of potential elite backers, like Cuadros, ultimately read the muddled signals as

${ }^{19}$ Translation by authors. 
strategic circumspection that could not be trusted (Cuadros Sánchez 2004). Sánchez Gironda managed to cobble together only a small coup coalition mainly with military backing; the plot ended in his arrest and imprisonment.

Building elite frustrations with Banzer were hardly limited to Cuadros. The powerful CEPB's calls for more consensual economic decision-making (participación concertada) in 1977 fell on deaf ears (Conaghan \& Malloy 1995, 87). Renewed instability and a military more fractionalized than ever exacerbated elite uncertainty about the likelihood of being able to draw a favorable new dictator. Sifting through the pool of potential autocrats did not turn up many attractive options. As Klein $(1992,262)$ notes, this catalyzed elites to throw their weight behind democratic elections, which was key to Banzer's retraction:

$[\mathrm{P}]$ robably most important of all, the new economic elite to which Banzer had made such important appeals just did not wish to continue to support the military in power. ...[T] hese middle and upper classes in Bolivia were more willing to trust their power in the democratic arena than to continue with a regime like Banzer's. With corruption and restlessness in the military at very high levels, and with officers representing every possible political line, the civilian elite could not trust the outcome of an anti-Banzer coup, since there was no way of knowing if the next leader would be a Torres, a Barrientos, or a Banzer... [R] ealizing that there existed a powerful moderate vote both in the urban and rural areas, the elite felt their needs could be better defended through civilian party rule.

\subsubsection{Uncertainty in the Informational Environment Increases}

Banzer was forced to call for elections in 1978 and chose a military successor, General Pereda, to run. As the tide turned in favor of the opposition leftist candidate Hernán Siles, Pereda carried out a successful coup. By this point, the CEPB was prominently pushing for a form of pacted democracy through a national grand bargain that embedded the rule of law as a protection to business (Conaghan \& Malloy 1995, 89). They also began repeatedly and publicly calling for a diminished role of the state in economic policy formation.

Civilian opposition to continued military rule forced new, inconclusive elections that yielded a caretaker government and another military coup. Rampant corruption, involvement in the cocaine trade, and the organization of paramilitary death squads generated intense 
opposition across the spectrum of civilian parties and groups (Klein 1992, 267). Economic growth ground to a halt. A new series of coups and countercoups alongside severe rentseeking made it impossible for elites to discern what any given military leader would do once in office. Consequently, the new string of dictators abandoned attempts to signal their appeal to elites and decoupled themselves from elite patrons.

The CEPB vocally renewed its call for a grand political and economic bargain that would usher in democracy and the rule of law. Conaghan \& Malloy $(1995,90)$ provide one CEPB leader's description of business's anxieties about continued military rule:

The Confederación first met in a group of very important entrepreneurs, who saw that there were great problems with [junta leader] García Meza - problems of trying to do things in ways that were not suitable for members of the private sector... And we saw that little by little, these problems were putting the military in a very difficult position. You see, we always looked at the military as an important means of saving us from the extreme left in this country. And the less prestige they had, the less we could count on them. ...And we knew that this meant that the longer [the military] stayed, the greater the chances that the extreme left would take over the country in a coup. And if that happened, we thought it would be hard to remove them. We could not allow the prestige of the military to suffer, so we started a campaign to begin a true democratic process.

\subsubsection{Democratic Transition}

Consequently, in 1982 the CEPB publicly pushed for the re-installation of the unseated Congress of 1980 with a "Democracy Now" campaign. The proposal gained wide support and formed the framework of democratization in 1982 when the ruling junta was forced from office (Conaghan \& Malloy 1995). Most popular sectors supported the proposal rather than trusting the unpredictable and highly interventionist military with new elections.

\section{Conclusion}

Recent influential scholarship on political regimes holds that the interests and actions of economic and political elites are generally fused under dictatorship. While this assumption has paved the way for elegant and parsimonious explanations of regime durability and change, 
it abstracts away from a key dynamic at the root of some of the most perplexing democratic transitions: the uncertainty that powerful economic elites have over whether the political elites who hold the levers of state power will act in economic elites' best interest.

This paper explores the consequences of this elite uncertainty for democratization. We outline two major types of uncertainty - uncertainty in a potential autocratic successor's policies generated by variance in the pool of would-be dictator types, and uncertainty in the truthfulness of policy promises made by potential autocratic successors. We build a formal model that generates predictions about how increases in these two types of uncertainty under dictatorship impact the decisions of economic elites to support a continuation of dictatorship or push for democracy. Finally, we demonstrate the plausibility of the theory by exploring several cases in which economic elite uncertainty under dictatorship ultimately catalyzed key economic elites to press for democracy.

The model in this paper conceives of two actors: a potential subsequent autocrat and the economic elites. However, it could also be applied to a situation in which the agent sending signals to economic elites is an incumbent dictator who seeks to transmit information about his future behavior. Although the median time in office for a dictator is roughly two years, making elite concerns with dictator replacement particularly salient, a quarter of all dictators since 1875 have survived in office five years or more (Goemans, Gleditsch \& Chiozza 2009). The model could be extended in these latter cases in which a current dictator is secure in power for the immediately foreseeable future. Doing so would entail modeling how the actions of an incumbent, relatively stable dictator could be interpreted by elites as signals of future behavior. Because the dictator's actions (i.e., the message levels) would directly enter the dictator's utility function, this would change his payoff structure. Nonetheless, like the model presented here, it would generate the possibility that elites lead the charge for democracy (and greater rule of law) catalyzed by uncertainty over potential future property rights transgressions by the dictator. Democratization in Indonesia and the Philippines demonstrate the plausibility of such an extension. Sidel (2008, 129), for instance, argues 
that capitalist elites withdrawing support for dictatorship was a necessary condition for the establishment of democracy in these countries.

Finally, this paper provides a novel explanation for why coup traps and regime cycling can at times come to an abrupt and surprising halt via a relatively stable and durable democratic transition. Explanations that lean on slow-moving variables such as modernization, inequality, or international diffusion have a hard time explaining why countries such as Argentina, Ghana, Peru, and Turkey became relatively stable democracies after decades of coups and regime cycling. A better explanation is that economic elites came to fear increasingly autonomous and unpredictable ruling militaries that flexed their muscles while in office; these elites then definitively cast their lot with democracy. Ironically, repeated coups sowed the seeds for eventually stable democracy. 


\section{References}

Acemoglu, Daron \& James Robinson. 2006. Economic Origins of Democracy and Dictatorship. New York: Cambridge University Press.

Acemoglu, Daron \& James Robinson. 2008. "Persistence of Power, Elites, and Institutions." American Economic Review 98(1):267-293.

Albertus, Michael. 2015. Autocracy and Redistribution: The Politics of Land Reform. Cambridge University Press.

Albertus, Michael \& Victor Menaldo. 2012. "If You're Against Them You're With Us: The Effect of Expropriation on Autocratic Survival." Comparative Political Studies 45(8):973-1003.

Albertus, Michael \& Victor Menaldo. 2014. "Gaming Democracy: Elite Dominance During Transition and the Prospects for Redistribution." British Journal of Political Science 44(3):575-603.

Ansell, Ben \& David Samuels. 2014. Inequality and Democratization: An Elite-competition Approach. New York: Cambridge University Press.

Arriola, Leonardo. 2009. "Patronage and Political Stability in Africa." Comparative Political Studies 42(10):1339-1362.

Ashworth, Scott \& Ethan Bueno de Mesquita. 2006. "Monotone Comparative Statics for Models of Politics." American Journal of Political Science 50(1):214-231.

Banks, Arthur \& Kenneth Wilson. 2015. "Cross-National Time-Series Data Archive.".

Bermeo, Nancy. 2010. "Interests, Inequality, and Illusion in the Choice for Fair Elections." Comparative Political Studies 43(8-9):1119-1147.

Boix, Carles. 2003. Democracy and Redistribution. Cambridge: Cambridge University Press.

Boix, Carles \& Milan Svolik. 2013. "The Foundations of Limited Authoritarian Government: Institutions, Commitment, and Power-Sharing in Dictatorships." The Journal of Politics 75(2):300-316.

Bratton, Michael \& Nicholas Van de Walle. 1997. Democratic Experiments in Africa. New 
York: Cambridge University Press.

Bueno de Mesquita, Bruce, Alastair Smith, Randolph Siverson \& James Morrow. 2003. The Logic of Political Survival. Cambridge, MA: MIT Press.

Caselli, Francesco, Tom Cunningham, Massimo Morelli \& Inés Moreno Barreda. 2014. "The Incumbency Effects of Signalling." Economica 81(323):397-418.

Cheibub, José Antonio, Jennifer Gandhi \& James Raymond Vreeland. 2010. "Democracy and Dictatorship Revisited." Public Choice 143(1-2):67-101.

CIA. 1971. Weekly Summary Special Report: Turnabout in Bolivia. Washington, D.C.: CIA. Conaghan, Catherine \& James Malloy. 1995. Unsettling Statecraft: Democracy and Neoliberalism in the Central Andes. Pittsburgh: University of Pittsburgh Press.

Cuadros Sánchez, Augusto. 2004. Ocaso de la Revolución Nacional Boliviana: Inestabilidad Militar y Democracia Formal: La Cuestión Monetaria. Los Amigos del Libro.

Cunningham, Tom \& Inés Moreno de Barreda. 2015. "Equilibrium Persuasion." Mimeo http://www.economics.ox.ac.uk/materials/events/13655/cm2015oxford.pdf.

Davies, Thomas \& Brian Loveman. 1997. The Politics of Antipolitics: The Military in Latin America. Lanham, MD: Rowman \& Littlefield.

Gandhi, Jennifer \& Adam Przeworski. 2007. "Authoritarian Institutions and the Survival of Autocrats." Comparative Political Studies 40(11):1279-1301.

Geddes, Barbara, Joseph Wright \& Erica Frantz. 2014. "Autocratic Breakdown and Regime Transitions: A New Data Set." Perspectives on Politics 12(2):313-331.

Gehlbach, Scott, Konstantin Sonin \& Milan Svolik. 2016. "Formal Models of Nondemocratic Politics." Annual Review of Political Science 19(1).

Gehlbach, Scott \& Philip Keefer. 2011. "Investment without democracy: Ruling-party institutionalization and credible commitment in autocracies." Journal of Comparative Economics 39(2):123-139.

Gilbert, Dennis. 1977. The Oligarchy and the Old Regime in Peru. PhD Dissertation, Cornell University. 
Goemans, Henk, Kristian Skrede Gleditsch \& Giacomo Chiozza. 2009. "Introducing Archigos: A Dataset of Political Leaders." Journal of Peace Research 46(2):269-283.

Goldstone, Jack. 1998. The Encyclopedia of Political Revolutions. Washington, D.C.: CQ Press.

Huntington, Samuel. 1968. Political Order in Changing Societies. New Haven: Yale University Press.

Janowitz, Morris. 1977. Military Institutions and Coercion in the Developing Nations. Chicago: University of Chicago Press.

Kamenica, Emir \& Matthew Gentzkow. 2011. "Bayesian Persuasion." American Economic Review 101(6):2590-2615.

Klein, Herbert. 1992. Bolivia: The Making of a Multi-Ethnic Society. Oxford: Oxford University Press.

Kuran, Timur. 1991. "Now out of Never: The Element of Surprise in the East European Revolution of 1989." World Politics 44(1):7-48.

Magaloni, Beatriz. 2008. "Credible Power-Sharing and the Longevity of Authoritarian Rule." Comparative Political Studies 41(4-5):715-741.

Mainwaring, Scott. 1999. Rethinking Party Systems in the Third Wave. Palo Alto, CA: Stanford University Press.

Marx, Karl \& Friedrich Engels. 1848. The Communist Manifesto. London.

Mayer, Enrique. 2009. Ugly Stories of the Peruvian Agrarian Reform. Durham: Duke University Press.

McClintock, Cynthia. 1983. Velasco, Officers, and Citizens: The Politics of Stealth. In The Peruvian Experiment Reconsidered, ed. Cynthia McClintock \& Abraham Lowenthal. Princeton: Princeton University Press pp. 275-308.

Miller, Michael. 2013. "Electoral Authoritarianism and Democracy: A Formal Model of Regime Transitions." Journal of Theoretical Politics 25(2):153-181.

Moore, Barrington. 1966. Social Origins of Democracy and Dictatorship. Boston: Beacon. 
Myerson, Roger. 2008. "The Autocrat's Credibility Problem and Foundations of the Constitutional State." American Political Science Review 102(1):125-139.

North, Douglass. 1990. Institutions, Institutional Change and Economic Performance. Cambridge: Cambridge University Press.

O’Donnell, Guillermo \& Philippe Schmitter. 1986. Transitions to Democracy. Baltimore, MD: Johns Hopkins University Press.

Palacios, Marco. 2006. Between Legitimacy and Violence: A History of Colombia, 1875-2002. Durham: Duke University Press.

Przeworski, Adam. 1991. Democracy and the Market. New York: Cambridge University Press.

Przeworski, Adam, Michael Alvarez, Jose Antonio Cheibub \& Fernando Limongi. 2000. Democracy and Development. New York: Cambridge University Press.

Rahat, Gideon \& Mario Sznajder. 1998. "Electoral Engineering in Chile: The Electoral System and Limited Democracy." Electoral Studies 17(4):429-442.

Schmitter, Philippe. 2010. "Twenty-Five Years, Fifteen Findings." Journal of Democracy 21(1):17-28.

Schulte-Bockholt, Alfredo. 2006. The Politics of Organized Crime and the Organized Crime of Politics: A Study in Criminal Power. Lexington Books.

Sidel, John. 2008. "Social Origins of Dictatorship and Democracy Revisited: Colonial State and Chinese Immigrant in the Making of Modern Southeast Asia." Comparative Politics 40(2):127-147.

Simpser, Alberto. 2013. Why Governments and Parties Manipulate Elections. New York: Cambridge University Press.

Slater, Dan. 2010. Ordering Power. New York: Cambridge University Press.

Svolik, Milan. 2009. "Power Sharing and Leadership Dynamics in Authoritarian Regimes." American Journal of Political Science 53(2):477-494.

Trimberger, Ellen Kay. 1978. Revolution from Above. Piscataway: Transaction Publishers. 
van de Walle, Nicolas. 2002. "Africa's Range of Regimes." Journal of Democracy 13(2):16-80. Wood, Elisabeth Jean. 2000. Forging Democracy from Below: Insurgent Transitions in South Africa and El Salvador. New York: Cambridge University Press.

Ziblatt, Daniel. 2009. "Shaping Democratic Practice and the Causes of Electoral Fraud: The Case of Nineteenth-Century Germany." American Political Science Review 103(1):1-21. 
Figure 1: Densities of types of potential autocrats

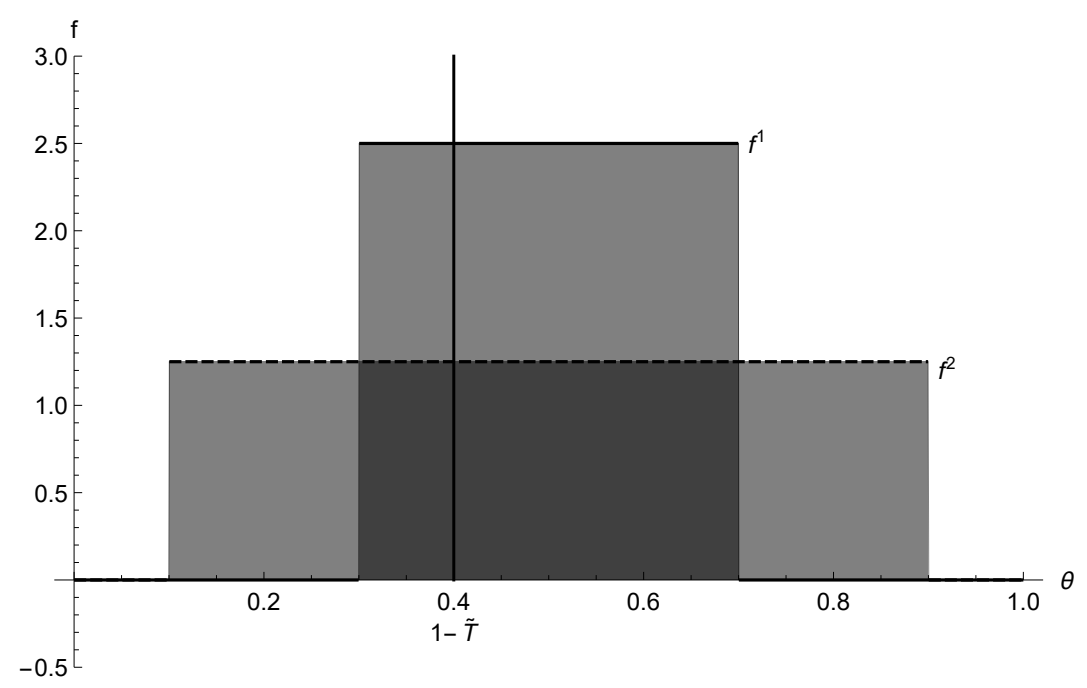

Parameters: $\mu=0.5, \sigma_{1, \theta}^{2} \simeq 0.013$ and $\sigma_{2, \theta}^{2} \simeq 0.033$ 
Figure 2: Autocrat's messaging strategy

(a)

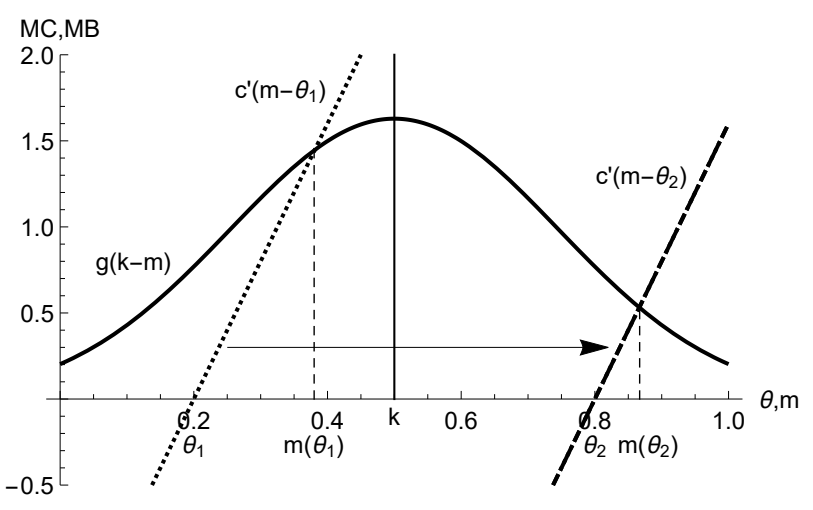

(b)

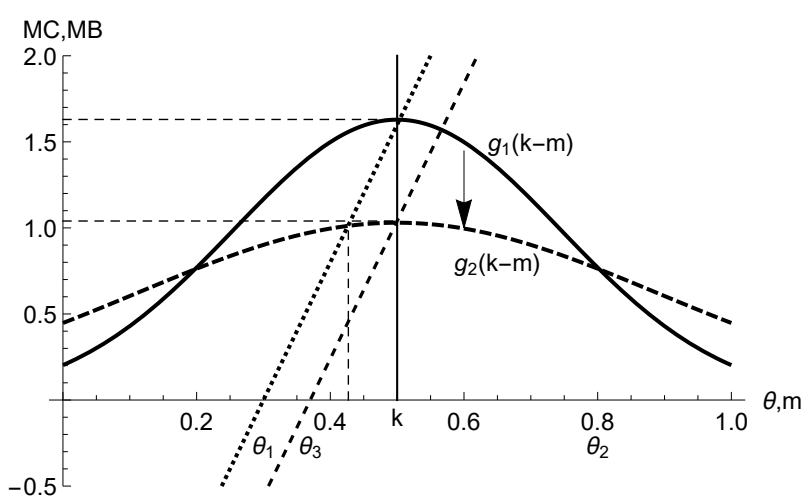

Parameters: $k=0.5, \sigma_{1, u}^{2}=0.06\left(\right.$ solid), $\sigma_{2, u}^{2}=0.15$ (dashed), $c=8, \theta_{1}=0.3, \theta_{2}=0.8, \theta_{3}=0.37$. 
Figure 3: Probability of democratization

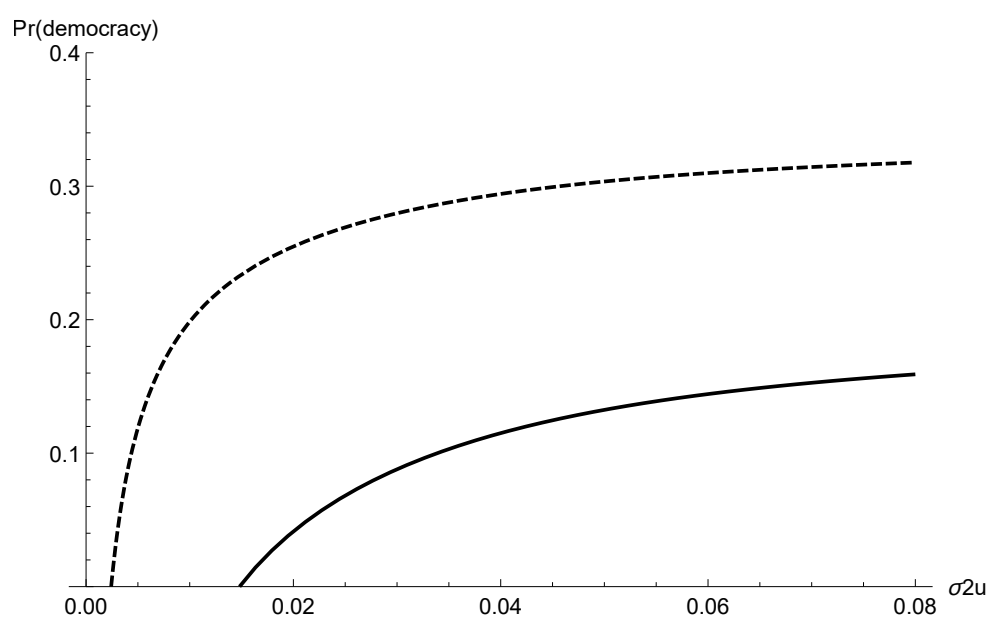

Parameters: $c=8, \nu=0.1, \sigma_{1, \theta}^{2}=0.02$ (solid curve), $\sigma_{2, \theta}^{2}=0.07$ (dashed curve) 


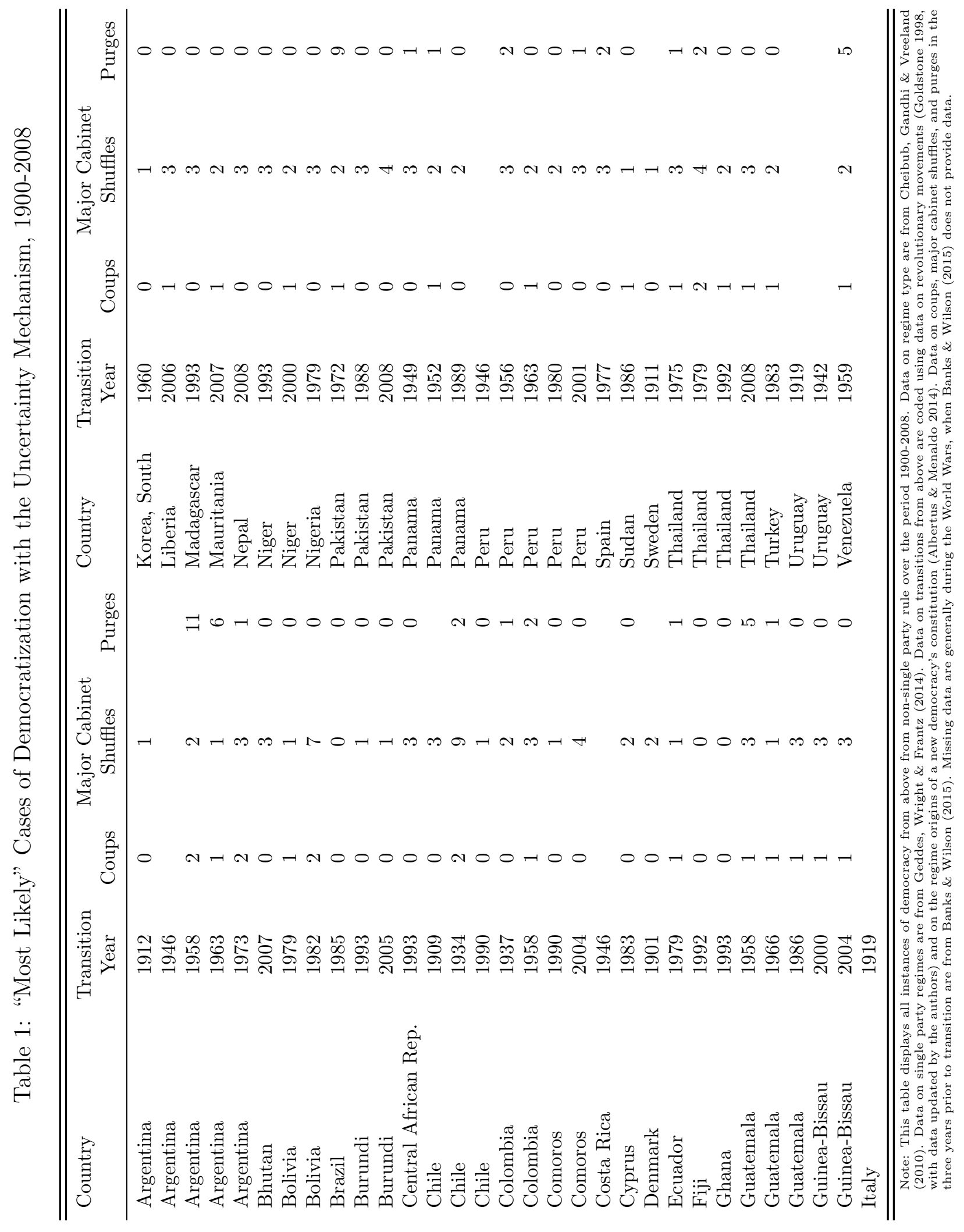

